\title{
BİR KOMUTAN Ve MÜFETTIŞ OLARAK MUHAMMED B. MESLEME
}

A Commander and Supervisor For Administrators: Muhammad bin Maslamah

\section{Abdulkerim ÖNER}

Dr. Öğr. Üyesi, Dicle Üniversitesi, İlahiyat Fakültesi, İslam Tarihi Anabilim Dalı

Assist. Prof., Dicle University, Faculty of Theology, Department of Islamic History Diyarbakır/Turkey

akerimoner@hotmail.com

ORCİD: 0000-0001-9643-1603

DOI: 10.34085/buifd.793275

Öz

Allah Resûlü'ne peygamberlik görevi verilmeden önce Medine'de dünyaya gelen Muhammed $b$. Mesleme, Medine'ye yapılan hicretten sonra onun yanından hiç ayrılmadı. Yerine vekil tayin edildiği Tebük Seferi hariç, Hz. Peygamber'in katıldığı savaşların tümüne iştirak etti. Allah Resûlü, yazdığı şiirleriyle Müslümanlara hakaret eden Ka'b b. Eşref'in öldürülme görevini ona verdi. Allah Resûlü'nün katılmadığı askerî birliklerin bazılarında komutan olarak görevlendirildi. Râşid Halifeler Dönemi'nde önemli görevlere getirildi. Özellikle vali ve vergi memurlarını denetlemesindeki üstün yeteneği ve gayretinden dolayı Hz. Ömer'in vazgeçemediği bir müfettişi hâline geldi. Sa'd b. Ebî Vakkas'ın Kûfe'deki kabilelerle yaşadığı sıkıntı ve yaptırdığı saray hakkında çıkan dedikoduların iç yüzünü araştırmak amacıyla görevlendirildi. Mısır valisi Amr b. Âs'ın fazla mal biriktirdiği ile ilgili söylemler üzerine oraya gönderilerek Amr'ın malına müsadere uyguladı. Hz. Ömer tarafından zekât âmili olarak görevlendirildi. Müslümanlar arasında çıkan fitnelerden uzak durdu. Hz. Peygamber'in hadisini gerekçe göstererek Hz. Ali'ye biat etmediği gibi Cemel ve Sıffin savaşlarına da iştirak etmedi.

Anahtar Kelimeler: İslam Tarihi, Denetleme, Müfettiş, Komutan, Muhammed b. Mesleme.

\section{Abstract}

Born in Madinah before Prophet Muhammad (PBUH) was assigned the duty of prophethood, Muhammad bin Maslamah declared his faith in the Beloved Prophet following the historic migration to Madinah and remained a devoted companion to him. Muhammad bin Maslamah participated in all the wars that the Beloved Prophet fought except when he was assigned a deputy during the Battle of Tabuk. The Beloved Prophet gave this companion the mission of destroying Ka'b ibn al-Ashraf, who insulted Muslims with his offensive and hurtful poems. He was even put in charge of commanding some of the military operations during which the Beloved Prophet was not physically present. He was also put in charge of some essential duties during the Caliphate Period. Thanks to his outstanding ability to supervise governors and tax officers, he became an indispensable supervisor for the second Caliphate, Omar bin Al Khattab. He was once appointed to investigate the gossip-based information spread about the problems that Sa'd b. Abi Waqqas had with the tribes of Kufah, as well as those spread about the palace Sa'd b. Abi Waqqas himself was having built then. Upon the rumours that Amr ibn al-'As, the governor of Egypt, had been accumulating too much property, Muhammad bin Maslamah was sent to Egypt to confiscate all his property. Moreover, he was made responsible for collecting alms on the order of the Caliphate Omar bin Al Khattab. However, he always remained cautious about distancing himself from the disturbances that occurred among the Muslims during the Caliphate Period. In fact, citing a hadith of the Beloved Prophet, he did not swear allegiance to the fourth Caliphate, Ali ibn Abi Talib, nor did he fight in the battles of Siffin and the Camel.

Keywords: İslam History, Inspection, Inspector, Command, Muhammad bin Maslamah. 


\section{Giriş}

Ebû Abdurrahman veya Ebû Saîd el-Medenî künyesiyle tanınan ${ }^{1}$ Muhammed b. Mesleme, bi'setten yirmi iki yıl önce dünyaya geldi. ${ }^{2}$ Evs kabilesinin Abduleşhel koluna mensuptur. ${ }^{3}$ Mus'ab b. Umeyr vasitasiyla Müslüman oldu. Hicretin akabinde Medine'de Ebû Ubeyde b. Cerrâh ile kardeş ilan edildi.. Gösterdiği kahramanlıklardan dolayı kendisine "Allah Resûlü'nün atlısı" denildi. ${ }^{5}$ Tebûk Gazvesi dışında Bedir ve Uhud savaşları başta olmak üzere Hz. Peygamber'in katıldığı bütün askeri ve sivil faaliyetlerinde yanından ayrılmadı. ${ }^{6}$ Tebûk Seferi'nde Hz. Peygamber, onu Medine'de yerine idareci/vekil olarak biraktı. ${ }^{7}$ Hz. Peygamber, Benî Süleym kabilesi üzerine gittiğinde yerine yine Muhammed'i vekil bıraktı. ${ }^{8}$

Benî Kaynukâ' Yahudilerinin yurtlarından sürülmesinden sonra geride bıraktıkları ganimetleri toplama görevi Muhammed'e verildi. (2/624) ${ }^{9}$ Bi'rimaûne'de (3/625) Müslüman tebliğcilerin pusuya düşürülüp şehit edildiğini duyan Allah Resûlü, aynı gece Muhammed b. Mesleme'yi oraya gönderdi. ${ }^{10}$ Hendek Gazvesi'nde Allah Resûlü'nün çadırını koruyanlardan biriydi. ${ }^{11}$ Benî Kureyza Yahudileri'nin teslim olduğu gece Müslümanların muhafızı idi. ${ }^{12}$ Allah Resûlü, Kureyzaoğullarının erkeklerinin ellerini bağlama ve kadınlarını esir etme görevini Muhammed'e verdi. ${ }^{13}$ Hudeybiye Barış Antlaşması'nın imzalanmasında şahitlik edenlerden biriydi. ${ }^{14}$ Dûmetülcendel Gazvesi'ne katıld1. ${ }^{15}$

Hz. Ali'nin halifeliği zamanında yaşadı ancak Allah Resûlü'nün Müslümanlar arasında savaş patlak verip fitne ve fesat ortaya çıktığı ortamdan uzak durmak gerektiği ile ilgili hadisini

${ }^{1}$ Muhammed b. Sa'd b. Menî ez-Zührî İbn Sa'd, Kitâbü't-tabakâti'l-kebîr (Kahire: Mektebetü'l-Hâncî, 2001), 3/408; Ebu'lFida İsmail b. Ömer, el-Bidâye ve'n-nihâye (Beyrut: Mektebetu'l-Maârif, 1990), 5/353.

2 Ebu'l-Fadl Ahmed b. Ali b. Muhammed, el-ísâbe fi temyizi's-sahabe, thk. Adil Ahmed Abdulmevcûd-Ali Muhammed Muavviz (Beyrut: Daru'1-Kutubi'1-ïlmiyye, 1415), 6/28.

${ }^{3}$ İbn Sa'd, Kitâbü't-tabakâti'l-kebîr, 3/408; Ebû Amr Halîfe b. Hayyât b. Halîfe eş-Şeybânî el-Basrî Halîfe b. Hayyât, Târîhu Halife b. Hayyât (Riyad: Dâru Tayyibe, 1985), 84; İbn Hacer, el-İsâbe fi temyizi's-sahabe, 6/28.

${ }^{4}$ İbn Kesîr, el-Bidâye ve'n-nihâye, 5/353.

${ }^{5}$ İbn Sa'd, Kitâbü't-tabakâti'l-kebîr, 3/410.

${ }_{6}$ İbn Kesîr, el-Bidâye ve'n-nihâye, 5/353.

7 İbn Sa'd, Kitâbü't-tabakâti'l-kebîr, 3/409; İbn Kesîr, el-Bidâye ve'n-nihâye, 5/7; Ahmed Cevdet Paşa, Kısas-ı Enbiya ve Tevârih-i Hulefâ, çev. Metin Muhsin Bozkurt (İstanbul: Çile Yayınları, ts.), 1/114.

${ }^{8}$ Halîfe b. Hayyât, Târîh, 58; Ebû Ömer Cemâlüddîn Yûsuf b. Abdillâh, el-İstî 'âb fì ma 'rifeti'l-ashâb (Beyrut: Daru'l-Cîl, 1992), 3/1377; İzzuddin Ebü'l Hasan Ali b. Muhammed, Üsdü'l-ğabe fi marifeti's-sahabe (Beyrut: Darü'1 Kütübi'l İlmiyye, 1994), 5/106.

${ }^{9}$ Ebû Hâtim Muhammed b. Hibbân, es-Sîretü'n-nebeviyye ve ahbâru'l-hulefâ, ed. Mehmet Azimli, çev. Harun Bekiroğlu (Ankara: Ankara Okulu Yayınları, 2017), 157; Muhammed b. Ebi Bekir b. Eyyub, Zâdu'l-meâd fi hedyi hayri'l-ibâd (Beyrut: Müessesetu'r- Risale, 1994), 3/115; Ebû Abdillâh Muhammed b. Ömer b. Vâkıd Vâkidî, Kitâbu'l-meğâazi (Beyrut: Dâru'lA'lemî, 1989), 1/178.

${ }^{10}$ Vâkidî, Kitâbu'l-meğâzi, 1/349.

${ }^{11}$ Vâkidî, Kitâbu'l-meğâzizi, 2/422.

12 Ebü'l-Feth Fethuddîn Muhammed, 'Uyûnü'l-esser fî fünûni'l-meġāzî ve'ş-şemẩil ve's-siyer, thk. İbrahim Muhammed Ramazan (Beyrut: Darü'l-Kalem, 1993), 2/104; Muhammed Abdulhay Kettânî, et-Teratibu'l-idâriyye (Beyrut: Darü'lErkam b. Ebi'l-Erkam, ts.), 2/288.

${ }^{13}$ İbn Sa'd, Kitâbü't-tabakâti'l-kebîr, 2/71.

${ }^{14}$ Ahmed b. Yahya b. Câbir b. Davud, Ensâbu'l-eşrâf (Beyrut: Dâru'l-Fikr, 1996), 1/350.

${ }^{15}$ Vâkidî, Kitâbu'l-meğâzi, 1/404. 
gerekçe göstererek kendisine biat etmedi. ${ }^{16}$ Ayrıca Müslümanlar arasında meydana gelen Cemel (36/656) ve Sıffîn (37/657) savaşlarına katılmayarak münzevi bir hayat yaşadı. ${ }^{17}$

Hz. Peygamber'in kâtiplerinden ${ }^{18}$ olan Muhammed b. Mesleme, fetva veren sahabiler arasında ismi geçmektedir.19 Aynı zamanda Allah Resûlü döneminde had cezasını uygulayanlardan biridir. ${ }^{20}$

Hz. Peygamber'den çok az hadis rivayet eden ${ }^{21}$ Muhammed, 43/663-664 y1lında yetmiş yedi² ${ }^{22}$ yaşında Medine'de vefat etti. ${ }^{23}$ Cenaze namazını Medine valisi Mervân b. Hakem kıldırdı. ${ }^{24}$

Muhammed b. Mesleme'nin hayatının ele alındığı bu çalışmada bütün hayatı teferruatlı bir şekilde incelenmemiştir. Hz. Peygamber döneminde seriyye komutanlığı ve bazı idari görevlerin yanında suikast ve infaz olayları ile Raşid Halifeler Dönemi'nde özellikle Hz. Ömer'in atadığı idarecileri denetlemedeki başarısı ve Hz. Osman'ın asilerle yaşadığı sıkıntılarda arabuluculuk görevinin üstlenmesi gibi konular üzerinde durulmuştur.

\section{Hz. Peygamber Dönemi}

Kaynaklarda ismine Hz. Peygamber'in Medine dönemiyle birlikte rastlanan Muhammed b. Mesleme, birçok alanda aktif rol oynamıştır. Bu da Hz. Peygamber'in onun kabiliyet ve karakterini çok iyi keşfettiğini ve kendisine güvendiğinin bir kanıtıdır.

\subsection{Ka'b b. Eşref'in Öldürülmesi (3/624-625)}

Anne tarafından Tay, baba tarafından ise Benî Nadîr kabilesine mensup olan Ka'b b. Eşref, Bedir Gazvesi'nden (2/624) sonra müşriklerin ölülerinin arkasında ağıtlar yakarak şiirler söylemiş ve onları Müslümanların aleyhine kışkırtmıştır. Allah Resûlü ve Müslümanlar hakkında olumsuz sözler söyleyerek fitneye sebep olmuş ve aynı zamanda Allah Resûlüne suikast düzenlemeye kalkışmıştır. Hem Müslümanların manevi şahsiyetine hem de onların lideri ve peygamberine hakaret eden bu zatın öldürülmesi gerekiyordu. Bazı kaynaklara göre Hz. Peygamber: "Bu görevi kim üstlenecek?" diye seslendiğinde Muhammed b. Mesleme: "ben yaparım" dediği rivayet edilirken ${ }^{25}$ başka kaynaklarda ise Muhammed b. Mesleme, bazı arkadaşlarıyla anlaşarak Allah Resûlü'nden bizzat görev talep etmiş, o da buna izin vermiştir. Muhammed, Allah Resûlü'nden Ka'b'ın hoşuna gidecek ve Müslümanları üzecek sözler söylemesi için gerekli izni aldıktan sonra arkadaşlarıyla birlikte onu öldürmek için hareket etmiştir. Soylu ve zengin olan Ka'b'ın yanına giderek Allah Resûlü'nü kötüleyici ifadeler

${ }^{16}$ Ebû Muhammed Abdullah b. Müslim, el-Imâme ve's-siyâse (Beyrut: Daru'l-Adva, 1990), 1/73; Muḥammad Âbid el-Câbirî, Arap ahlaki akli: Arap kültüründeki değer düzenlerine yönelik çözümleyici eleştirel bir araştırma, çev. Muhammed Çelik (İstanbul: Mana Yayınları, 2015), 78.

17 İbn Abdilberr, el-ìstî 'âb fî̀ ma 'rifeti'l-ashâb, 3/1377.

18 İbn Kesîr, el-Bidâye ve'n-nihâye, 5/353; Kettânî, et-Teratibu'l-idâriyye, 1/151.

${ }^{19}$ Ebu Muhammed Ali b. Ahmed, Cevâmiu's-sîre, çev. M. Salih Arı (İstanbul: Çıra Yayınları, 2004), 302.

${ }^{20}$ Kettânî, et-Teratibu'l-idâriyye, 1/258.

${ }^{21}$ İbn Hacer, el-İsâbe fi temyizi's-sahabe, 6/28.

${ }^{22}$ Kırk üç yaşında vefat ettiği aktarılır. Halîfe b. Hayyât, Tabakat, thk. Süheyl Zükkar (Beyrut: Daru'1-Fikr, 1993), 147; Kırk altı veya kırk yedi yaşlarda vefat ettiğine dair bk. İbnü'l-Esîr, Üsdü'l-ğabe fi marifeti's-sahabe, 5/106.

${ }^{23}$ Halîfe b. Hayyât, Târîh, 206; İzzuddin Ebü'l Hasan Ali b. Muhammed İbnü'l-Esîr, el-Kâmil fi't-târih, thk. Ömer Abdusselam et-Tedmirî (Beyrut: Dârü'1 Kitâbi'l Arabiyye, 1997), 3/26.

${ }^{24}$ İbn Sa'd, Kitâbü't-tabakâti'l-kebîr, 3/410; İbnü'l-Esîr, el-Kâmil fi't-târih, 3/26.

${ }^{25}$ Ebû Abdullah Muhammed b. İsmail Buhârî, el-Câmi 'u's-sahîh (Beyrut: Dâru İbn Kesîr, 2003), Mağazî, 15; İbn Sa'd, Kitâbü't-tabakâti'l-kebîr, 2/28. 
kullanmış ve onun güvenini kazanmayı başarmıştır. Daha sonra arkadaşlarıyla birlikte ona tuzak kurup öldürmüştür. Böylece Allah Resûlü'nü memnun etmiştir. ${ }^{26}$

Ka'b b. Eşref'in öldürülmesi hadisesi, bazı Yahudilerin hoşuna gitmemiş ve "Muhammed haksız yere adam öldürüyor" söylemleriyle Allah Resûlü hakkında kara propaganda yapmışlardır. Bunu duyan Allah Resûlü, "O da başkaları gibi kendi halinde durup hakaret etmeseydi öldürülmezdi. Ancak o, durmadan Müslümanları rahatsız edici şiirler söyledi. Müslümanların aleyhinde hakaretvari ifadeler kullanan kim olursa olsun hakkı kılıçtır." diyerek onun haksız yere öldürülmediğini ifade etmiştir. ${ }^{27}$

Ka'b b. Eşref'in öldürülmesinden yıllar sonra Mervân b. Hakem'in Medine valisi olduğu bir dönemde Yahudi İbn Yâmîn ile oturduklarında Mervân, “Ka'b b. Eşref'in öldürülmesini nasıl buluyorsun?" diye sorduğunda İbn Yâmîn: "Bir zulümdü" dedi. Bu cevaba karşılık Mervan, İbn Yâmîn'e olumsuz bir şeyler söylememiş olmalı ki o esnada orada bulunan ve yaşlanmış olan Muhammed: “Ey Mervân! Sana göre Allah Resûlü zulüm yapmış öyle mi? Vallahi biz onu ancak Resûlüllah'ın izniyle öldürmüştük ve o, öldürülmeyi hak etmişti." diyerek Mervân'a çok sert tepki göstermiştir. ${ }^{28}$

\subsection{Uhud Gazvesi (3/625)}

Bedir Gazvesi'nden sonra müşrikler, Müslümanlardan intikam almak istediler. Bu durumdan haberdar olan Allah Resûlü, ashabiyla istişare ettikten sonra Uhud'da müşriklerle savaşmaya karar verdi. Savaş başlamadan önce Müslümanlar geceyi Şeyheyn'de geçirdiler. Hz. Peygamber, Müslümanları koruma görevini Muhammed b. Mesleme'ye verdi. Elli kişilik bir muhafız grubunun başında bulunan Muhammed, gece Müslümanlara saldırmak üzere gelen Müşrik süvarilerini geri püskürtmeyi başard $1 .{ }^{29}$

Ensarın silahşor ̈̈30 ${ }^{30}$ olarak bilinen Muhammed b. Mesleme, Uhud Gazvesi'nde Müslümanların zor anlar yaşadığı ve bazı sahabîlerin yerlerini terk ederek Allah Resûlü'nü yalnız bıraktıkları bir esnada onun etrafından dağılmayarak onu korumaya çalışan birkaç sahabîden biriydi. Hz. Peygamber, savaş sonunda Uhud şehitlerini kontrol etme görevini de ona verdi. Aynı zamanda yaralanan Müslümanları tedavi edip kadınlarla birlikte onların su ihtiyaçlarını gidermeye çalıştı. Hatta Allah Resûlü ve yaralı mücahitlere verecek su kalmayınca Teymîlerin evlerinin yanındaki kumluk bir yerde su bulup getirdi ve Allah Resûlü'nün duasına mazhar oldu. ${ }^{31}$

26 Ebu'l Huseyn el-Haccâc el-Kuşeyrî en-Nîsâbûrî, Sahîh'u-Muslim (Riyad: Dâr'u-Taybe, 2006), Cihâd, 119; Ebû Dâvûd Süleyman b. Eş'as, Sünenu Ebî Dâvud (Beyrut: Dâru'r-Risâletu'l-Âlemiye, 2009), Harâc, 22; Muhammed b. Müslim b. Ubeydullah, el-Meğâzî, ed. Mehmet Azimli, çev. Mehmet Nur Akdoğan (Ankara: Ankara Okulu Yayınları, 2016), 103; Muhammed b. İshâk b. Yesâr, Sîretu İbn İshâk, thk. Muhammed Hamidullah (Konya: Hayra Hizmet Vakfı Neşriyat, 1981), 297-299; İbn Sa'd, Kitâbü't-tabakâti'l-kebîr, 2/28; Ebû Zeyd Abdurrahmân b. Muhammed, Kitâbü'l- '̇̉ber, thk. Halil Şehâde (Beyrut: Daru'l-Fikr, 1988), 2/431; Mehmed Âş1k Hanefî, Târîh-i Mekke-i Mükerreme ma'al Medîne-i Münevvere, çev. Mehmet Karataş-Davut Adlığ-Abdullah Cengiz (Ankara: Gece Akademi, 2019), 150.

${ }^{27}$ Abdurrahman Re'fet el-Bâşa-Halid Muhammed Halid-Abdulaziz eş-Şennâvî, Sahabe Hayatından Tablolar, çev. Tâceddin Uzun (Konya: Kervan Yayınları, 2018), 145-146.

${ }^{28}$ Vâkidî, Kitâbu'l-meğâzi, 1/192-193.

29 İbn Seyyidünnâs, 'Uyûnü'l-esser, 2/14; Huseyn b. Muhammed b. Hasan Diyârbekrî, Târîhu'l-hamîs fi ahvâli'l-enfesi nefîs (Beyrut: Daru Sadr, ts.), 1/422.

30 İbn Kuteybe, el-imâme ve's-siyâse, 1/121.

${ }^{31}$ Ebû Abdillâh Muhammed b. Ömer, Kitâbu'l-meğâzi (Beyrut: Dâru'l-A'lemî, 1989), 1/237, 249-250. 


\subsection{Benî Nadîr Gazvesi (4/625)}

Hz. Peygamber, Medine'ye hicret ettikten sonra Nadîroğullarının da içinde bulunduğu bir antlaşma gerçekleştirdi. Ancak Yahudiler hiçbir zaman güven vermediler. Neticede aralarındaki ilişki bozuldu. Müslümanlarla Benî Nadîr Yahudileri arasında ilişkilerin bozulması ile ilgili iki rivayet gösterilmektedir. Bunlardan birincisi, Bedir Gazvesi'nden sonra Müslümanların aleyhine Mekkeli müşrikler ile Nadîroğulları arasında bir mutabakatın gerçekleşmesidir. Bunun üzerine Benî Nadirliler, kendi din adamlarıyla konuşmaları ve onları ikna ettiği takdirde Müslüman olacağına dair Allah Resûlü'ne haber göndererek yurtlarına davet ettiler. Bundan maksat Hz. Peygamber'i yurtlarına getirerek ona suikast düzenlemekti. Ancak Allah Resûlü, Bir görüşe göre vahiy yoluyla; ${ }^{32}$ başka bir görüşe göre ise Yahudilerin arasında yaşayan ensarlı bir hanımın durumu kendisine bildirmesi üzerine onların tuzağından kurtuldu. ${ }^{33}$

Müslümanların Benî Nadîr Yahudileriyle aralarının bozulmasına sebep olan ikinci rivayet ise Allah Resûlü'nün 4/625 tarihinde Âmir b. Sa'saa kabilesine göndermiş olduğu yetmiş sahabînin şehit edilmesi olayıdır. Rivayet edildiğine göre Allah Resûlü'nün gönderdiği tebliğciler, Bi'rimaûne denilen yerde pusuya düşürülerek şehit edilmişlerdir. Bu olaydan sağ kurtulan Amr b. Ümeyye ed-Damri, Medine'ye dönerken yolda arkadaşlarını şehit eden kabileden oldukları zannıla iki kişiyi öldürmüştü. Dolayısıyla maktulün ailesine diyet ödenmeliydi. Müslümanlarla olan anlaşmaları gereği ${ }^{34}$ Benî Nadîr Yahudilerinin de diyetin bir kısmını ödemeleri gerekiyordu. Hz. Peygamber, bu durumu onlara haber verince onlar da aralarında müzakere etmek üzere Hz. Peygamber'i yurtlarına davet ettiler. Amaçları ise ona tuzak kurarak öldürmekti. Hz. Peygamber, birkaç sahabîyle birlikte Benî Nadîr yurduna gidince onların kurdukları tuzaktan haberdar oldu. Yanında bulunanlara haber vermeden hemen oradan ayrılarak Medine'ye geri döndü. ${ }^{35}$

Her iki rivayette de görüldüğü gibi Benî Nadîr Yahudileri, Allah Resûlü'ne suikast düzenlemeye çalışmışlardır. Bu duruma çok kızan Allah Resûlü, hemen Muhammed b. Mesleme'yi çağırarak Benî Nadîr yurduna gitmesini, onların bir an önce Medine'yi terk etmelerini, yaptıkları suikast planlarının yanlarına kâr kalmayacağını, Müslümanlarla aynı yerde yaşamayacaklarını ve on gün ${ }^{36}$ içerisinde yurtlarını terk etmedikleri takdirde gereken cezaya uğrayacaklarını bildirmesini istedi. ${ }^{37}$

Muhammed de Benî Nadîr yurduna giderek onlara şöyle seslendi: "Ben Allah Resûlü'nün elçisiyim. Size iletmem gereken bir durum için buradayım. Ancak bildiğiniz bir şeyi size hatırlatmadan onu size söylemeyeceğim." dedikten sonra konuşmasını şu şekilde sürdürdü: "Allah'ın Musa'ya

${ }^{32}$ Ebu Ca'fer Muhammed b. Cerîr Taberî, Târîhu'r-rusûl ve'l-mulûk, thk. Muhammed Ebû'l-Fadl İbrahim (Kahire: Dâru'lMeârif, ts.), 2/552.

33 İbn Şihâb ez-Zührî, el-Meğâzî, 61-62; Muhammad Hamidullah, Hz. Peygamber'in Savaşları, çev. Nazire Erinç Yurter (İstanbul: Beyan Yayınları, 2012), 204.

${ }^{34}$ Hicretten sonra Allah Resûlü, Medine'deki Yahudi kabileleriyle bir antlaşma imzalamıştı. Antlaşma gereği Yahudi kabileleri, Mekke müşrikleriyle ittifak kurmamaları, savaş masrafları, diyet ve fidyelerin ödenmesi gibi konularda beraber hareket etmeleri kararlaştırılmıştı. Ancak mezkûr kabileler, görünüşte antlaşmaya sadık kalmakla birlikte arka planda her fırsatta müşriklerle ittifak kurarak Müslümanlara ihanet etmişlerdir. Bk. Nuh Arslantaş, Yahudilere Göre Hz. Muhammed ve İslâmiyet: İbranîce Tarih kitapları Açısından Bir İnceleme (İstanbul: İz Yayıncılık, 2011), 115.

${ }^{35}$ Ebû Muhammed Cemâlüddîn Abdülmelik, es-Sîretu'n-nebeviyye (Beyrut: Dâru'l-Kitabu'l-Arabî, 1990), 3/143-144; İbn Kesîr, el-Bidâye ve'n-nihâye, 4/74-75.

36 Üç gün diyen rivayetler de bulunmaktadır. Bk. İbn Kesîr, el-Bidâye ve'n-nihâye, 4/75.

37 Taberî, Târîhu'r-rusûl ve'l-mulûk, 2/552; İbn Hibbân, es-Sîretü'n-nebeviyye ve ahbâru'l-hulefâ, 178. 
indirdiği Tevrat hakkı için bana doğru söyleyin. Hatırlıyor musunuz Allah Resûlü, peygamber gönderilmeden önce size gelmiştim. Tevrat'ın önünüzde olduğu bir mecliste bana, 'Ey İbn Mesleme! Sana yemek vermemizi istersen yemek veririz. Şayet Yahudi olmak istersen seni Yahudi yaparı.' demiştiniz. Ben de size 'Vallahi ben Yahudi olmayacağım, siz bana yemek verin.' demiştim. Siz ise 'Seni dinimize girmekten meneden ancak ... güler yüzlü, hikmetle konuşan ve savaşşı biridir demiştiniz.' Yahudiler ise 'Evet doğru söyledin ama o bir peygamber değildir.' deyince Muhammed, 'Ben sözümü söyledim tercih sizindir." dedikten sonra Allah Resûlü'nün mesajını iletti. ${ }^{38}$ Bunun üzerine Yahudiler: "Evs kabilesinden birinin bu haberi getireceğini beklemezdik." dediler. Muhammed, "Allah kalplerimizi değiştirdi. İslam bundan önceki antlaşmaları geçersiz saydr." diyerek onları susturdu. ${ }^{39}$

Allah Resûlü'nün Evs kabilesinden Muhammed'i Benî Nadîr Yahudilerine göndermesi manidardır. Zira İslam öncesi dönemde Evs kabilesi ile Benî Nadîr kabilesi müttefikti. Allah Resûlü'nün elçi olarak Evs kabilesinden birini Nadîroğullarına göndermesi, stratejik olarak yalnız kalmalarını ve herhangi bir dostlarının kalmadığını hissettirmekti. Onun içindir ki Nadîroğulları kendilerine elçi olarak Muhammed b. Mesleme'nin gönderilmesine çok şaşırmışlardır.

Benî Nadîr kabilesi, yaptıkları ihanetin farkına varmalarına rağmen Allah Resûlü'nün çağrısına direndiler. Bunun sebebi ise münafıkların kendilerine destek olacağına dair söz vermeleridir. Ancak müttefikleri olan münafıklardan istedikleri desteği alamayınca gitmeyi kabul ettiler. Onların Medine'den çıkarılması,${ }^{40}$ mallarının ve cephaneliklerinin teslim alınması görevi de Muhammed'de verildi. ${ }^{41}$

\subsection{Kuratâ Seriyesi (5-6/627)}

Hz. Peygamber, Muhammed b. Mesleme'yi otuz kişilik süvari bir askeri birliğin komutasında Bekir b. Kilâboğulların'dan el-Kuratâ kolu üzerine gönderdi.42 Bu kabile, Medine'ye yedi günlük uzaklıkta Dariyye yönünde Bekerât denen yerde ikamet ediyordu. ${ }^{43}$

Muhammed ve arkadaşları, Allah Resûlü'nün tavsiyesi gereği gündüzleri gizlenip geceleri yollarına devam ettiler. Onlardan gizlenmeyi başaran birlik, Kuratâ halkına baskın düzenlediler. Ancak kadın ve çocuklara dokunmadılar. Deve, sığır ve koyunlardan oluşan bol miktarda ganimet ele geçirdiler. Bu ganimetleri getirip Allah Resûlü'ne teslim ettiler. Allah Resûlü de ganimetlerin beşte birini ayırdıktan sonra diğerlerini mücahitler arasında bölüştürdü. ${ }^{44}$

Muhammed, bu seriyye esnasında Sümâme b. Üsâl el-Hanefîye'yi yakalayarak Medine'ye getirdi. Hz. Peygamber de onu mescidin direğine bağladı ve İslamiyet'e davet etti. Ancak Sümâme, Müslüman olmayı kabul etmedi. İki üç gün direğe bağlı kaldıktan sonra Hz. Peygamber, onu salıverdi. Sümâme, özgürlüğüne kavuştuktan sonra Müslüman oldu. ${ }^{45}$

\footnotetext{
38 Vâkidî, Kitâbu'l-meğ âzi, 1/366-367.

${ }^{39}$ Taberî, Târîhu'r-rusûl ve'l-mulûk, 2/552; İbn Hibbân, es-Sîretü'n-nebeviyye ve ahbâru'l-hulefâ, 178.

${ }^{40}$ Vâkidî, Kitâbu'l-meğâzi, 1/374.

${ }^{41}$ Vâkidî, Kitâbu'l-meğ âzi, 1/377.

${ }^{42}$ İbn Hibbân, es-Sîretü'n-nebeviyye ve ahbâru'l-hulefâ, 203.

${ }^{43}$ İbn Sa'd, Kitâbü't-tabakâti'l-kebîr, 2/74.

${ }^{44}$ Vâkidî, Kitâbu'l-meğâazi, 2/534; İbn Sa'd, Kitâbü't-tabakâti'l-kebîr, 2/74; el-Belâzurî, Ensâbu'l-eşrâf, 1/376.

${ }^{45}$ Sümâme'nin Müslüman olma süreci hakkında bk. İbn Hibbân, es-Sîretü'n-nebeviyye ve ahbâru'l-hulefâ, 203.
} 


\subsection{Zülkassa Seriyyesi (6/627)}

Benî Sa'lebe, Benî Muhârib ve Enmâr kabileleri, kuraklıktan dolayı zor günler geçirdiler. Medine dışında Heykâ bölgesinde Müslümanlara ait olan hayvanlara baskın düzenleme planı içerisindeydiler. Hz. Peygamber, bu olaydan haberdar olunca Muhammed b. Mesleme'yi on kişilik askeri bir birliğin komutasında Sa'lebe b. Sa'doğulları yurdu olan Zülkassa'ya ${ }^{46}$ gönderdi. ${ }^{47}$

Zülkassa halkı, Müslümanların kendi üzerlerine geleceklerini haber alınca hazırlık yaptılar. Yüz kişiden oluşan müşrikler, mücahitleri takip ederek uyumalarını beklediler. Ardından onlara tuzak kurarak ağır bir darbe vurdular. Muhammed'in arkadaşları şehit olurken kendisi yaralı olarak kurtulmayı başardı. Mücahitlerin hepsinin öldüğünü zanneden bedeviler, onların elbiselerini alarak gittiler. Daha sonra Müslümanlardan biri, Muhammed'e rast gelerek onu Medine'ye getirdi. Allah Resûlü, saldırıya uğrayan Müslümanların intikamını almak için Ebû Ubeyde b. Cerrah önderliğinde bir birlik gönderdi. Ancak müşrikler, Müslümanların geldiklerini haber alınca dağlara kaçtılar. Mücahitler, müşrikleri yerlerinde bulamayınca onlardan geri kalan bazı ganimetleri alarak Medine'ye geri döndüler. ${ }^{48}$

\subsection{Hayber Gazvesi (7/628)}

Muhammed b. Mesleme, Müslümanlarla Yahudiler arasında meydana gelen Hayber Gazvesi'ne katılarak Müslümanlar için karargâhın belirlenmesinde önemli rol oynadı. Rivayet edildiğine göre Müslümanların mevzilendikleri yerin karargâh için uygun olmadığını gören bazı sahabîler, durumu Allah Resûlü'ne bildirdiler. Bunun üzerine Allah Resûlü, Muhammed'i çağırarak kendisinden Yahudilerin kalelerinden ve bulaşıcı hastalıktan uzak aynı zamanda onlardan gelebilecek saldırılardan emin bir karargâh yeri bulmasını tembihledi. Bunun üzerine Muhammed, uygun bir yer bulmak amacıyla etrafı dolaşmaya başladı. Neticede er-Recî denen yerin uygun olduğu kanaatine vardı. Geceleyin Allah Resûlü'nün yanına dönerek karargâh için uygun bir yer bulduğunu bildirdi. Allah Resûlü de Muhammed'in gösterdiği yere karargâh kurdu. ${ }^{49}$

Bütün uğraşlara rağmen Yahudiler teslim olmayınca kuşatma başladı. Bu esnada Yahudi Merhab, Müslümanlardan birini mübarezeye davet edince Muhammed b. Mesleme, Hz. Peygamber'in izniyle onun karşısına çıktı ve onu öldürdü..$^{50}$

\subsection{Umretü'l-Kazâ (7/629)}

Hudeybiye Antlaşması'ndan bir sene sonra Hz. Peygamber, kazâ umresi yapmak amacıyla Zülhuleyfe'ye gitti ve burada bir gece konakladı. Kurban edilmesi için bazı develeri işaretledi ve onları önceden Mekke'ye doğru gönderdi. Kurbanlıkların olası bir saldırı durumunda müdahale etmek amacıyla Muhammed b. Mesleme'nin komutasında yetmiş̧ ${ }^{51}$ veya yüz kişilik

\footnotetext{
${ }^{46}$ Zülkassa, Rebeze yolu üzerinde Medine'ye yirmi dört mil uzaklıkta bulunan bir yerdir. İbn Sa'd, Kitâbü't-tabakâti'l-kebîr, $2 / 81$.

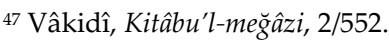

${ }^{48}$ el-Belâzurî, Ensâbu'l-eşrâf, 1/377; Halîfe b. Hayyât, Târîh, 78; Taberî, Târîhu'r-rusûl ve'l-mulûk, 2/641; İbnü'l-Esîr, el-Kâmil fi't-târih, 2/87; İbn Kayyim el-Cevziyye, Zâdu'l-meâd fi hedyi hayri'l-ibâd, 3/251.

${ }^{49}$ Vâkidî, Kitâbu'l-meğâzi, 2/644.

${ }^{50}$ Halîfe b. Hayyât, Târîh, 82; Taberî, Târîhu'r-rusûl ve'l-mulûk, 3/14; Merhab'1 öldüren kişinin Hz. Ali olduğuna dair rivayetler de bulunmaktadır. İbnü'l-Esîr, her iki rivayeti de ele almaktan sonra Hz. Ali'nin öldürdügüne dair rivayeti daha isabetli bulmaktadır. Bk. el-Kâmil fi't-târih, 2/98.

51 Taberî, Târîhu'r-rusûl ve'l-mulûk, 3/25-26.
} 
bir birliği öncü kuvvet olarak gönderdi. ${ }^{52}$ Muhammed, Merrü'z-Zehrân'a geldiğinde Kureyş halkından bir grupla karşılaştı. Onlar Hz. Peygamber'in durumunu sorunca Muhammed, Hz. Peygamber'in yolda olduğunu ve bir müddet sonra buraya ulaşacağını söyledi. Kureyş halkı, Muhammed ve arkadaşlarının silahlı olduğunu görünce endişeye kapılıp durumu Mekkelilere bildirdiler. Onlar da Hz. Peygamber'e haber göndererek antlaşma gereği silahsız gelmeleri gerektiğini hatırlattılar. Hz. Peygamber, bu hususta endişelenecek bir durumun olmadığını bildirdikten ${ }^{53}$ sonra konuşmasını şu şekilde sürdürdü: "Ben küçüklü̈̆̈̈mden beri vefakârlık ve doğrulukla tanındım. Mekke'ye silahla girmek arzusunda değilim. Sadece silahların bana yakın bir yerde bulunmasını istedim." ${ }^{54}$ Allah Resûlü, kendisinden emin ancak Kureyşlilere güvenmediğinden silahlı gitmiş olması muhtemeldir. Zira onun bütün hayatı incelendiğinde, verdiği sözden asla geri adım atmadığı görülmektedir.

\section{Râşid Halifeler Dönemi}

\subsection{Hz. Ebû Bekir}

Allah Resûlü'nün vefatından sonra Müslümanların kimin tarafından idare edileceği ile ilgili Benî Sâide Sakifesi'nde yapılan müzakerelerde Hz. Ebû Bekir halife seçildi. Daha sonra Müslümanların geneli kendisine biat etmesine rağmen azınlıkta olan birkaç kişi biatını geciktirdi. Bunlardan biri de Hz. Ali ile yakınlığı bilinen Zübeyr b. Avvâm idi. Bu durum büyük sıkıntılara sebebiyet vermemekle birlikte bazı kırgınlıkların oluşmasına yol açtı. Buna seyirci olmayan ve olayların daha da büyümesine engel olmaya çalışanlardan biri de Muhammed $b$. Mesleme'dir. Rivayet edildiğine göre Muhammed, Zübeyr b. Avvâm'ın kılıcını kırarak yatıştırıcı rol oynadı..$^{55}$

Hz. Ebû Bekir, halife seçildiğinde bazı kabileler, daha önce amiller aracılığıyla toplanan zekâtları vermek istemediler. Bazı sahabîlerin karşı çıkmasına rağmen halife, onlarla savaşmaya karar verdi. Bu amaçla Medine'deki Müslümanları onlara karşı kendi yanında savaşmaya davet etti. Böylece muhacir ve ensardan oluşan, sayıları yüz civarında olan askeri bir birlik halifenin komutasında şehirden ayrıldı. Hz. Ebû Bekir bu işte o kadar kararlıydı ki Medine halkının tamamen hazırlanmasını beklemeden zekât vermek istemeyenlerin üzerine yürüdü. Hazırlıklarını yapamayan diğer Müslümanların sevk ve idaresini Muhammed b. Mesleme'ye bırakarak yoluna devam etti. Medine'de halifenin yerine vekil birakılan Muhammed, halkı zekât vermeyenlere karşı cihada teşvik etti. ${ }^{56}$

Hz. Ebû Bekir'in halifeliği döneminde idarecileri teftiş ettiği ile ilgili muahhar kaynaklarda ${ }^{57}$ bilgi olsa da bunu klasik kaynaklardan teyit ettiremedik. Allah Resûlü'nün itimat ettiği ve birçok önemli görev verdiği Muhammed'in Hz. Ebû Bekir zamanında pasif durumda kalması düşünülemez. Ancak bununla alakalı yaptığımız araştırmada net bir bilgiye ulaşamadık.

\subsection{Hz. Ömer}

Hz. Ömer, vali ve âmillerinin halka nasıl davrandığını anlamak için belli aralıklarla müfettiş göndererek onları denetliyordu. Bu hususta rastgele kişileri değil de işinde mahir, görevini

\footnotetext{
${ }^{52}$ İbn Sa'd, Kitâbü't-tabakâti'l-kebîr, 3/409; İbn Seyyidünnâs, 'Uyûnü'l-esser, 2/192.

53 İbn Kesîr, el-Bidâye ve'n-nihâye, 4/231.

${ }^{54}$ Taberî, Târîhu'r-rusûl ve'l-mulûk, 3/26.

${ }^{55}$ Ebû Abdullah Muhammed b. Ahmed, Târîhu'l-İslam ve vefeyâtu'l-meşâhîr ve'l-a'lam, thk. Ömer Abdusselam et-Tedmirî (Beyrut: Dâru'l-Kutubî'l-Arabî, 1993), 3/13.

${ }^{56}$ Mustafa Fayda, Allah'ın Kilıcı Halid b. Velid (İstanbul: İFAV Yayınları, 2016), 249.

${ }^{57}$ Ataullah Şahyar, “Muhammed b. Mesleme”, Türkiye Diyanet Vakfi İslam Ansiklopedisi (Erişim 18 Ağustos 2020).
} 
hakkıyla yerine getiren ve bu konuda kendisine güven veren Muhammed b. Mesleme'yi görevlendiriyordu. Taşrada herhangi bir yerde bir şikâyet söz konusu olduğunda olayı araştırmak için hemen onu gönderiyordu. Muhammed de tahkikat için gittiği yerlerde işini gizleyerek değil, aleni bir şekilde yerine getiriyordu. Şikâyetçileri, şahitlerle birlikte herkesin huzurunda dinliyordu. Hem şikâyetçiler hem de şahitler çekinmeden, herhangi birinin tesiri altında kalmadan ifade veriyorlardı. Çünkü Hz. Ömer'in ona bu konuda sınırsız yetki verdiklerini çok iyi biliyorlard1. ${ }^{58}$

Ashabın en faziletleri arasında gösterilen ${ }^{59}$ ve çözülmesi güç olan meselelerin çözümü için sürekli Hz. Ömer'in yanında bulunan ${ }^{60}$ Muhammed, görevini yerine getirirken son derece hassas davranmış, şüphe uyandıracak hususlardan uzak durmaya çalışmıştır. Hatta kendisine sunulan yemeklere bile temkinli yaklaşmıştır. İbn Abdürabbi şöyle bir olay aktarmıştır: Hz. Ömer, Amr b. Âs'ın malını araştırması için Muhammed'i Mısır'a gönderdiğinde Amr, kendisi için bol miktarda yemek yaptırmıştı. Ancak Muhammed, yemekleri yemek istememiştir. "Bu yemekler haram mı?" diye soran Amr'a, Muhammed, şöyle cevap vermiştir: "Şayet bu yemekleri misafir olduğum için bana ikram ediyorsan onlardan bir miktar yerim ancak başka bir niyetin varsa Allah'a yemin ederim ki ondan bir bardak su bile içmem." ${ }^{61}$ diyerek bu konudaki hassasiyetini dile getirmiştir.

Kadisiye Savaşı'ndan (15/636) sonra Sasanilerin başkenti olan Medâin, Müslümanların eline geçince mücahitler geçici olarak oraya yerleştirildi. Bölgenin iklim şartlarına ayak uyduramayan Müslüman Arapların rutubetli ortam ve sivrisineklerin çokluğundan dolayı sağlıkları bozuldu. Bununla birlikte deve ve koyunları da zarar gördü. Irak genel komutanı Sa'd b. Ebî Vakkas, bu durumu Hz. Ömer'e bildirdi. Halife, ordugâh şehir için Medine ile aralarında nehir bulunmayan uygun bir yer bulmasını istedi. Yapılan araştırmalar neticesinde yerleşmeye müsait arazi bulunarak Kûfe ${ }^{62}$ adıyla yeni bir şehir kuruldu. ${ }^{63}$

Kûfe, belirli bir plan çerçevesinde inşa edildi. Şehrin ortasında mescid yapıldı. Onun hemen yanında Sa'd b. Ebî Vakkas için bir ev inşa edildi. Kamıştan yapılan bu eve görkemli bir kapı monte edildi. ${ }^{64} \mathrm{Bu}$ ev, daha sonra Kûfe'de $S a^{\prime} d^{\prime}$ ın Sarayı olarak anıldı. İhtişamıyla ön plana çıkan bu saray, halk arasında dedikodulara sebep oldu. ${ }^{65}$ İbn Kesîr, Sa'd b. Ebî Vakkas'ın halkın yüksek sesinden rahatsız olduğu ve bunun için evine böyle bir kapı taktırdığını aktarır. ${ }^{66}$ Hatta bu kapının Medâin'deki Kisra'nın köşkünün kapısı olduğu, Kûfe'ye getirilerek Sa'd'ın köşküne monte edildiği rivayet edilmektedir. ${ }^{67}$

Hz. Ömer, bu durumdan haberdar olunca olayın içyüzünü öğrenmek amacıyla Muhammed b. Meslme'yi Kûfe'ye gönderdi. Haberin doğru olması durumunda sarayın kapısını yakması

\footnotetext{
58 İbnü'l-Esîr, Üsdü'l-ğabe fi marifeti's-sahabe, 5/106; Mustafa Fayda, “Hz. Ömer Devri”, Doğuştan Günümüze Büyük İslam Tarihi (İstanbul: Çağ Yayınları, 1986), 2/180.

59 İbn Abdilberr, el-İstî 'âb fì ma 'rifeti'l-ashâb, 3/1377.

${ }^{60}$ İbn Hacer, el-İsâbe fi temyizi's-sahabe, 6/28.

${ }^{61}$ Ebû Ömer Şihâbüddîn Ahmed b. Muhammed, el-Ikdu'l-ferîd (Beyrut: Dâru'l-Kutubi'l-İlmiyye, 1983), 1/46.

62 Yakut, Mu'cemü'l-buldân, Kûfe, 4/490; Geniş bilgi için bk. Casim Avcı, "Kûfe", Türkiye Diyanet Vakfi İslam Ansiklopedisi (Erişim 04 Ağustos 2020).

${ }^{63}$ Ahmed b. Yahya b. Câbir b. Davud el-Belâzurî, Fütûhu'l-büldân (Beyrut: Mektebetü'l-Meârif, 1987), 387.

${ }^{64}$ el-Belâzurî, Fütûhu'l-büldân, 391.

${ }^{65}$ İbnü'l-Esîr, el-Kâmil fi't-târih, 2/354.

${ }^{66}$ İbn Kesîr, el-Bidâye ve'n-nihâye, 7/75.

${ }^{67}$ Fayda, "Hz. Ömer Devri", 2/81.
} 
talimatında bulundu. Muhammed, Kûfe'ye gidip bazı tetkikleri yaptıktan sonra sarayın kapısını yaktı. Bu durumdan haberdar olan Sa'd b. Ebî Vakkas, "Bu iş için gönderilmiş bir elçidir." diyerek onu yanına çağırdı fakat Muhammed onun yanına gitmedi. Bunun üzerine Sa'd, Muhammed'in yanına gitti. ${ }^{68}$ Muhammed, Sa'd'a halifenin olaylardan haberdar olduğunu ve insanların yüzüne kapıyı kapatmanın doğru olmadığını, halkın huzuruna girmesine engel olan herhangi bir nöbetçinin bulunmaması gerektiğini tembihledi.69 Ardından halifenin mektubunu Sa'd b. Ebî Vakkas'a verdi. Mektupta şunlar yazılıydı:

"Bana senin kale gibi bir saray yaptırdığın bilgisi ulaştı. Seninle halkın arasını ayıran bu saraya Sa'd'ın Sarayı deniliyormuş. Üstelik Kisra'nın sarayının kapısını da getirip kendi sarayında kullanmışsın. Kapına adamlar koyup ihtiyaç sahiplerini menetmişsin. Allah Resûlü'nün yolunu bırakıp Kisraların yolunu takip etmişsin. Kisrayı o saraydan mezara indirdiler ve saray kendisine bir fayda vermedi. Bu saray senin değil, fitne ve fesat yuvasıdır. Bu saraydan çık, beytülmâle yakın bir yere yerleş ve sarayı da kapat. Aksi takdirde bu sarayın üzerinde hiç kimsenin giremeyeceği bir kapı yaparız. Ben sana Muhammed b. Mesleme'yi o sarayı yakması için gönderiyorum. $O$, senden asla korkmayacak."

Sa'd, mektubu okuyunca çok mahcup oldu. Sarayı terk ederek mütevazı bir eve taşınacağını ve halifenin emirlerine uyacağını söyledi. Daha sonra Muhammed'e herhangi bir ihtiyacının olup olmadığını sordu. Hatta kendisine maddi yardımda bulunmayı teklif etti. Fakat Muhammed bu teklifi kabul etmedi. Ardından Muhammed, yaşananları halifeye bildirmek üzere Medine'ye geri döndü. ${ }^{70}$

\subsubsection{Sa'd b. Ebî Vakkas'ın Görevden Alınması}

Kûfe şehri kurulduktan sonra oranın genel valisi Sa'd b. Ebî Vakkas olmuştu. Topraklarının büyük bir kısmını özellikle başkentlerini kaybeden Sasaniler, Müslümanlara karşı büyük bir savaş hazırlığına başlamışlardı. Bunların öncü kuvvetleri Nihavend'e ulaşınca Sa'd bir taraftan hazırlık yapmış diğer taraftan da hem halifeyi durumdan haberdar etmek hem de ondan yardım almak amacıyla Medine'ye haber göndermişti. İşte bu esnada el-Cerrâh b. Sinân elEsedî'nin de aralarında bulunduğu bir grup Kufeli, Vali Sa'd b. Ebî Vakkas'a karşı isyana girişmişlerdi. Düşmanın harekete geçişine pek aldırış etmemiş ve valimiz iyi namaz kıldırmıyor gerekçesiyle Medine'ye gelip onu halifeye şikâyet etmişlerdi. ${ }^{71}$

Hz. Ömer, Kûfe'den gelen heyetin iyi niyetli olmadığını, şerli insanlar olduklarını anlamış ve bunu yüzlerine vurmuştur. Zira onlara: "Sa'd, bu olağanüstü şartlarda düşmanlarınızla uğraşırken siz kalkı onu şikâyete gelmişsiniz. Allah'a yemin ederim ki bu tavrınızdan dolayı başınıza gelecek felaketten size acımayacak ve sizlere karşı tedbir almaktan vazgeçmeyeceğgim. Buna rağmen sizin şikâyetlerinizi dikkate alıp durum incelemesi için birini görevlendireceğgim." demiştir. ${ }^{72}$

Halife Ömer, yaşanan bu olaylardan son derece üzülmüş ve olayların aydınlığa kavuşması için uğraşmıştır. İşte bu amaçla hem Kûfe'de Müslümanlar arasında çıkan anlaşmazlıkların içyüzünü öğrenmek hem de düşman ordusuna karşı takviye amacıyla Muhammed b. Mesleme komutasında bir heyet göndermiştir. Hz. Ömer zamanında İslam coğrafyasının herhangi bir yerinde halk ile yöneticiler arasında çıkan anlaşmazlıkları gidermek amacıyla bölge hakkında

\footnotetext{
68 İbnü'l-Esîr, el-Kâmil fi't-târih, 2/354.

${ }^{69}$ İbn Kesîr, el-Bidâye ve'n-nihâye, 7/75.

70 el-Belâzurî, Fütûhu'l-büldân, 391; İbnü'l-Esîr, el-Kâmil fi't-târih, 2/354; İbn Kesîr, el-Bidâye ve'n-nihâye, 7/75; Fayda, “Hz. Ömer Devri", 2/82.

71 İbnü'l-Esîr, el-Kâmil fi't-târih, 2/390; İbn Kesîr, el-Bidâye ve'n-nihâye, 7/106.

72 İbnü'l-Esîr, el-Kâmil fi't-târih, 2/390; İbn Kesîr, el-Bidâye ve'n-nihâye, 7/106.
} 
bilgi almak ve gerektiğinde cezai müeyyideyi uygulamak için gönderilen ilk kişi Muhammed'dir. ${ }^{73}$

Muhammed b. Mesleme, Kûfe'ye gittiğinde Sa'd b. Ebî Vakkas'la görüşmeden önce halk ile görüşmeye karar verdi. Onlara olaylar hakkında neler bildiklerini rahat bir şekilde söylemelerini ve validen çekinmemeleri gerektiğini ifade ederek hakikatin ortaya çıkmasına gayret etti. Bunun için onlarla valinin huzurunda değil de kendilerini rahat bir şekilde ifade edebilecekleri cami gibi yerlerde görüşmeyi uygun gördü. Bununla yetinmeyen Muhammed, kabile reisleriyle tek tek görüştü. Bu amaçla vali hakkında bilgi toplamaya çalıştı. Hem halk hem de kabile reislerinin geneli Sa'd hakkında olumlu ifadeler kullanırken Cerrâh el-Esedî'nin etrafında toplananlar, vali hakkında pek olumlu konuşmadılar. Muhammed, Sa'd hakkında Abeseoğullarıyla da görüştü. Onlardan Üsâme b. Katâda, Sa'd hakkında şunları söyledi: "Allah'a yemin ederim ki o, malları eşit bir şekilde paylaştırmıyor, adaletle hükmetmiyor ve askerlerle birlikte savaşlara katılmıyor."74

İbn Haldûn, bu olayların arka planında asabiyetin olduğunu ve diğer Arap kabilelerin Kureyş'in üstünlüğünü kabullenemediğini söyler. Kabileler, bunu direk söyleyemediklerinden onların kendilerine zulüm ve düşmanlık ettiğini, ganimetleri adaletli bir şekilde dağıtmadıklarını ve dolayısıyla haksızlığa uğradıklarını iddia etmişlerdir. ${ }^{75}$

Muhammed b. Mesleme, halkla gerekli görüşmeleri yaptıktan sonra bölge valisi Sa'd b. Ebî Vakkas'la görüştü. Ona isnat edilen suçlamalar hakkında bilgi almak istedi. Özellikle halkın sesinden rahatsız olduğu gerekçesiyle sarayına monte edilen kapı ile ilgili meseleyi sordu. Sa'd, hakkında söylenen olumsuz sözlerin gerçeği yansıtmadığını ve iftiraya maruz kaldığını söyledi. ${ }^{76}$

Cennetle müjdelenmiş on kişiden biri olup din uğruna aç kalmış, çeşitli sıkıntılara maruz kaldığı halde sabretmiş olan ${ }^{77} \mathrm{Sa}^{\prime} \mathrm{d}$ b. Ebî Vakkas, söylenenleri kabul etmemiştir. Zira Müslümanların ilklerinden olup müşriklerin kanını ilk akıtan kişinin kendisi olduğunu belirtmiştir. Ayrıca Allah Resûlü'nün "Anne babam sana feda olsun” ifadesini kendisinden başka hiç kimse için kullanmadığını ifade etmiş ve konuşmasını şu şekilde sürdürmüştür: "Hal böyleyken, nasıl oluyor da Esedoğullarının iddia ettiği gibi iyi namaz klldırmıyor, İslamiyet'i bir tarafa bırakıyor ve avcllıkla oyalanıyorum. ${ }^{78}$ Şayet durum böyle ise ben amelinin sevabın kaybetmiş ve zarara uğramış kişilerden olurum."79 diyerek kendisini savunmuştur.

Kendisi hakkında söylenenlere çok üzülmüş olmalı ki hasımlarına karşı şöyle beddua etti: "Allah'ım! Şayet onlar benim hakkımda söyledikleri sözleri riya için söylemişlerse gözlerini kör et. Onları çoluk çocuklarıyla imtihan eyle..." dedikten sonra rivayetlere göre Sa'd b. Ebî Vakkas'a iftira edenler, Sa'd'ın bedduasına mazhar olup büyük bir sıkıntıya maruz kaldıkları nakledilmektedir. 80

\footnotetext{
${ }^{73}$ İbnü'1-Esîr, el-Kâmil fi't-târih, 2/390.

${ }^{74}$ el-Belâzurî, Fütûhu'l-büldân, 391.

75 Ebû Zeyd Veliyyüddîn Abdurrahmân b. Muhammed, Mukaddime, çev. Halil Kendir (Ankara: İmaj Yayınevi, 2004), $1 / 301$.

76 İbnü'l-Esîr, el-Kâmil fi't-târih, 2/391; İbn Kesîr, el-Bidâye ve'n-nihâye, 7/106.

77 Ahmed Cevdet Paşa, Kısas-ı Enbiya, 1/318.

78 İbnü'l-Esîr, el-Kâmil fi't-târih, 2/391.

79 İbn Kesîr, el-Bidâye ve'n-nihâye, 7/106.

80 İbnü'l-Esîr, el-Kâmil fi't-târih, 2/391.
} 
Netice itibariyle Muhammed $b$. Mesleme hem halkı hem de valiyi dinledikten sonra belli bir kanaate vardı. Ardından halifenin emrini Kûfelilere bildirdi ve Sasanilerle savaşa katılmaları gerektiğini söyledi. Daha sonra Sa'd b. Ebî Vakkas ile muhaliflerini Medine'ye Hz. Ömer'in huzuruna getirdi. Halifeye Kûfe'de yaşadıklarını anlattı. Böylece Hz. Ömer, Muhammed'i dinledikten sonra Sa'd b. Ebî Vakkas'ı hesaba çekti ve nasıl namaz kıldırdığını sordu. Sa'd: "Allah Resûlü'nün halka namaz kıldırdığı gibi dört rek'atlık bir namazın ilk iki rekâtını uzun; son iki rekâtını ise kısa keserim." dedi. Bunun üzerine halife: "Biz de seni böyle biliyorduk Ey Ebâ İshâk! İşte senin hakkında dedikodulara sebebiyet veren hadise budur. Ĕger ihtiyatl davranmazsak bu işin sonu hayırlı olmaz." dedikten sonra olayların önüne geçmek için çalışmalarını sürdürdü. ${ }^{81}$

Hz. Ömer, Sa'd'la yaptığı görüşmeler neticesinde onun suçsuz olduğuna inandığı halde toplumun birlik ve beraberliğinin zarara uğrayacağına ve olası bir fitnenin önüne geçmek amacıyla ihtiyaten de olsa Sa'd'ı görevinden almıştır. Halifenin Sa'd'ın suçsuz olduğuna inandığının en büyük delillerden biri ise yaralandığg zaman kendisinden sonra halife seçilecek şûra heyetine, "Her kim halife olursa Sa'd'ı Kûfe'ye vali olarak görevlendirsin." ifadesidir. ${ }^{82}$

\subsubsection{Amr b. Âs'ı Denetlemesi}

Hz. Ömer, kendi halifeliği zamanında haksız kazancın önüne geçmek için valilerini görevlendirmeden önce onların mallarını tespit etmek amacıyla mal beyannamesini hazırlatmıştır. ${ }^{83}$ Ayrıca başkalarına yük olmamaları ve halkın malına göz dikmemeleri için kendilerine yüksek miktarda maaş bağlamıştır. ${ }^{84}$ Yani idarecilerinin gayrimeşru herhangi bir servet biriktirmelerine müsaade etmemiştir. Bunun için her yola başvurmuştur. Hatta suiistimal ihtimalini göz önünde bulundurarak gizli bir şekilde servet biriktirenlerin önüne geçmek amacıyla vali ve âmillerini Medine'ye gece gelişlerini bile yasakladığı rivayet edilmektedir. ${ }^{85}$

Halife tarafından alınan bütün tedbirlere rağmen zaman zaman bazı idarecilerinin mallarının beklenenden fazla artış olduğu görülmüştür. Bu durum Hz. Ömer'in dikkatinden kaçmamıştır. Mesela Mısır'a vali olarak görevlendirilen Amr b. Âs, kendisine verilen maaşın dışında fazla mal biriktirdiği ile ilgili haberlerin duyulması üzerine halife, Amr b. Âs'tan savunma istemiştir. Amr'ın gönderdiği mektuptan kuşkulanan halife, kendisine bir mektup yazarak Muhammed b. Mesleme'ye verip göndermiştir. Mektupta şunlar yazılmıştır: "Kötü âmiller hakkında yeterince bilgilendirildim. Senin bana gönderdiğin mektup, doğru yolda olanlarm huzurunu kaçıran bir mektuptur. Bunun için senin hakkında şüphelerim var. Olayı araştırmak ve şayet fazla çıkması durumunda malını taksim etmesi için Muhammed'i gönderiyorum. Senden ne isterse onu yerine getir. Sana sert davranırsa onu bağışla. Çünkü o, gizli olan şeyleri dışarı çıkarır." 86

Muhammed, Mısır'a gitmiş ve yaptığı araştırmalar neticesinde Amr'ın masraflarının artmasını sebep göstererek bölge topraklarının verimliliği ve ticaretten elde edilen kazançtan kendisine pay ayırdığını tespit etmiştir. Halifenin bu tür durumlara tahammülünün olmadığını bilen Muhammed, Amr'dan bütün mal varlığını getirmesini istemiştir. Halifenin emriyle orada olduğunu bilen Amr, söylenenlere itiraz etmemiş ve bütün malını Muhammed'in önüne

${ }^{81}$ İbnü'l-Esîr, el-Kâmil fi't-târih, 2/391-392; İbn Haldûn, Kitâbü'l- '̇̉ber, 2/556.

82 Buhârî, Fezâilü Ashâbi'n-Nebî, 8.

83 İbn Sa'd, Kitâbü't-tabakâti'l-kebîr, 3/263; el-Belâzurî, Fütûhu'l-büldân, 307-308.

${ }^{84}$ Ebû Yusuf Ya'kub b. İbrahim, Kitabü'l-harâc (Beyrut: Darü'l Ma'rife, 1979), 113; Abdulaziz b. İbrahim el-Ömerî, elVilayetu ala'l-buldan fi asri'l-hulafâi'r-raşidîn (Riyad: Dâru İşbiliyâ, 2001), 201.

${ }^{85}$ Cengiz Kallek, Asr-ı Saâdet'te Yönetim-Piyasa İlişkisi (İstanbul: İz Yayıncılık, 1997), 97.

${ }^{86}$ Belâzurî, Fütûhu'l-büldân, 308; Ebü'l-Ferec Kudâme b. Ca'fer, el-Harâc ve sinâ'atu'l-kitâbe, thk. Muhammed Zeydî (Bağdat: Dâru'r-Raşîd, 1981), 339. 
sermiştir. Muhammed de yaptığı araştırmalar neticesinde Amr'ın olması gerekenden daha fazla servet biriktirdiğini tespit etmiş ve fazlasına el koymuştur. ${ }^{87}$ Bazı rivayetlere göre ise Muhammed, onun ayakkabılarına varıncaya kadar tüm mal varlığının yarısına el koymuştur. ${ }^{88}$

Malının Muhammed tarafından müsadere edilmesini kabullenemeyen ve son derece üzülen Amr b. Âs, kendi aile büyükleri ile halifenin ailesini karşılaştırdı ve onu tenkit etti. Bu duruma seyirci kalmayan Muhammed, Amr'a şöyle karşılık verdi: “Böyle şeyler söyleme! Şayet kötü gördüğün Ömer'in zamanı olmasaydı, evinin önünde bağh duran keçin ile meşgul olur, onun fazla süt vermesine sevinir, sütünün azalması durumunda ise üzülürdün." Bunun üzerine Amr, konuşulanları halifeye ulaştırmaması için Muhammed'e ricada bulundu. Muhammed de aralarındaki konuşmaları emanet olarak algıladı ve Hz. Ömer'e anlatmadı. ${ }^{89}$

\subsection{3. Âmillerin Denetlenmesi}

Hz. Peygamber'den itibaren herhangi bir yere vergi toplamak amacyyla görevlendirilen memurlar, sıkı bir denetime tabi tutulmuş ve görevlerini suiistimal edenler ciddi bir şekilde uyarılmıştır. ${ }^{90} \mathrm{~Hz}$. Ömer de aynı hassasiyeti devam ettirmiştir. O görevlendirdiği âmillerini, halka karşı dikkatli olmaları gerektiğini vurgulamış ve onlara takatlerinin üstünde sorumluluk yüklememeleri gerektiğini tembihlemiştir. ${ }^{91}$ Hukuka aykırı hareket eden âmillerini ikaz etmekle yetinmemiş ${ }^{92}$ gerektiğinde sert tedbirlere başvurmuştur. ${ }^{93}$

Hz. Ömer, halkı küçümseyip onlara farklı muamelede bulunanlara karşı iyi niyetli olmamıştır. Bir yere vali veya âmil tayin ettiği zaman ince ve yumuşak elbise giymeme, değerli bineklere binmeme, elenmiş undan yapılmış has ekmekten yememe ve kapısında insanların huzuruna girmesini engelleyecek herhangi birini bulundurmama gibi şartları koşmuştur. Nitekim rivayet edildiğine göre halife, caddede yürüdügü bir esnada halktan biri kendisine, “İdarecileri tayin ederken onlara bazı şartları öne sürmüşsün. Ancak senin Mısır'a vergileri toplamakla görevlendirdiğin İâz b. Ganm b. Zübeyr, ince elbiseler giyiyor, kapısına hâcib dikiyor ve halktan farklı bir şekilde davranmaya çalışıyor ki bu da halkta rahatsızlığa yol açıyor." dedi. Bunun üzerine Hz. Ömer, olayın mahiyetini yerinde tespit etmek amacıyla, Muhammed b. Mesleme'yi Misır'a göndererek olayı detaylı bir şekilde araştırmasını şayet anlatılanlar doğru ise İyâz'ı alıp Medine'ye getirmesini tembihledi. ${ }^{94}$ Zira Hz. Ömer, âmilleriyle ilgili olayları bildirmek ve onlarla alakalı kendisine ulaşan şikâyetleri araştırmak amacıyla genellikle Muhammed'i görevlendirirdi..$^{95}$

Muhammed b. Mesleme, Mısır'a giderek gerekli tetkikleri yapınca söylendiği gibi İyâz'ın kapısında hâcib olduğunu ve halktan farklı bir şekilde giyindiğini görmüştür. Bunun üzerine halifenin emrini kendisine bildirmiş ve hemen Medine'ye gelmesi gerektiğini söylemiştir. İyâz b. Ganm, üzerindeki kıyafetleri değiştirip öyle gelmek isteyince Muhammed, buna müsaade

\footnotetext{
87 el-Belâzurî, Fütûhu'l-büldân, 308; Kudâme b. Ca'fer, el-Harâc ve sinâ'atu'l-kitâbe, 339.

88 İbn Abdürabbih, el-Ikdu'l-ferîd, 1/46.

${ }^{89}$ el-Belâzurî, Fütûhu'l-büldân, 308.

${ }^{90}$ Ebû Yusuf, Kitabü'l-harâc, 81, 82; Ebû Ubeyd Kasım b. Sellam, Kitâbü'l-emvâl, thk. Dr. Muhammed Ammare (Beyrut: Darü'ş-Şuruk, 1989), 358; Yusuf el-Kardâvî, İslam Hukukunda Zekât, çev. İbrahim Sarmış (İstanbul: Kayıhan Yayınları, 1984), 2/72.

${ }^{91}$ Ebû Yusuf, Kitabü'l-harâc, 114.

92 İbn Abdürabbih, el-Ikdu'l-ferîd, 1/44.

${ }_{93}$ Muslim, Libas, 2; Ebû Ubeyd, Kitâbü'l-emvâll, 157.

${ }^{94}$ Ebû Yusuf, Kitabü'l-harâc, 116.

${ }^{95}$ Kettânî, et-Teratibu'l-idâriyye, 1/228.
} 
etmemiş ve bulunduğun hal üzerine halifenin huzuruna çıacaksın karşlığını vermiştir. Bunun üzerine Muhammed, onu Medine'ye getirip halifeye teslim etmiştir. Hz. Ömer, İyâz'ı görünce üzerindeki elbiseleri çıkarmasını ve başka bir elbise giymesini söyledikten sonra bir hayvan sürüsünü teslim ederek kendisine şöyle seslenmiştir: "Yün gömleğini giy, eline bir değnek al ve şu koyunlar güt. Onların sütünden iç, ihtiyacı olanlara da ver. Şayet arta kalan olursa onu da getir." İyâz b. Ganm, "Ölmek bundan daha hayırlıdır." karşıllğını vermiştir. Hz. Ömer: "Neden bu kadar tepki verdin ki senin baban koyun güttü̈̆̈̈ için kendisine ganm/çoban denilmiyor muydu, bu iş senin için daha hayırlı değil mi?" dedikten sonra "şartlarımı yerine getireceğine dair bana söz verecek misin?" sorusuna İyâz "evet" cevabını vermiştir. Daha sonra yaptıklarına pişman olan İyâz, halife tarafından Mısır'a eski görevine iade edilmiştir. ${ }^{96}$

\subsubsection{Zekât Memuru Olarak Görevlendirmesi}

Zekâtlar, Hz. Peygamber döneminden itibaren devlet eliyle toplanıyordu. ${ }^{97}$ Daha sonra Râşid halifeler de aynı yolu takip ettiler..$^{98} \mathrm{Hem} \mathrm{Hz}$. Peygamber hem de halifeler, güvendikleri ehil kişilere bu görevi veriyorlardı. Zira zekât memurları, sadece vergileri toplamak için değil aynı zamanda oranın hem valisi hem de İslam'ı tebliğ görevinde bulunuyorlardı. ${ }^{99}$ Onun için son derece hassas davranmaları gerekiyordu.

Zekât âmilleri arasında Muhammed b. Mesleme'nin adı da geçmektedir. Kendisine seriyye komutanlığı ve müfettişlik görevlerinin yanında zekâtları toplama görevi de verilmiştir. Nitekim Hz. Ömer tarafından Benî Cüheyne kabilesine ${ }^{100}$ zekât âmili olarak görevlendirilen Muhammed, görevini son derece hassas bir şekilde yerine getirmiştir. Zekât amaciyla kendisine getirilen hayvanları iyice incelemiştir. Zekâta uygun olanları almış diğerlerini ise sahiplerine iade etmiştir. ${ }^{101}$

Bilindiği gibi Hz. Peygamber zamanından itibaren farklı bölgelere gönderilen âmiller, topladıkları gelirleri ilk önce oranın fakirlerine dağıtmış, fazla kaldığı takdirde merkeze göndermişlerdi. ${ }^{102} \mathrm{~Hz}$. Ömer döneminde de aynı uygulama devam etmiştir. Rivayet edildiğine göre halife, Muhammed'i zekât memuru olarak görevlendirmiş, o da topladığı zekâtları ihtiyaç sahiplerine dağıtmış ancak nasıl olmuşsa bazılarını unutmuştur. Zekâttan pay alamayan ihtiyaç sahibi bedevi bir kadın, Medine'ye gelerek Muhammed'in durumunu halifeye anlatmıştır. Hz. Ömer de Muhammed ve kadını yüzleştirmiştir. Kadının mağdur durumda olduğunu anlayınca Muhammed'i uyarmış ve üstlendiği görevin hassasiyetinden bahsetmiştir. Ayrıca kadının ihtiyaçlarını karşılamış, bundan sonra böyle bir sıkıntının yaşanmayacağını bildirmiştir. ${ }^{103}$

Muhammed $b$. Mesleme, sadece valileri ve âmilleri değil, yeri geldiğinde halifeyi de açık bir dille uyarmıştır. Nitekim o, Hz. Ömer'in devletin gelirlerini artırdığını ve bu anlamda insanları maddi olarak rahatlattığını, halka âdil bir şekilde muamele ettiğini ve bunun için de onun hakkında hayırla dua ettiğini bildirmiştir. Ancak yanlış yapması durumunda ateşin oka şekil

\footnotetext{
${ }^{96}$ Ebû Yusuf, Kitabü'l-harâc, 116; İbnü'l-Cevzî, el-Muntazam fî târîhi'l-mülûk ve'l-ümem, 4/137.

${ }^{97}$ Muhammed Hamidullah, Allah'ın Elçisi Hz. Muhammed, çev. Ülkü Zeynep Babacan (İstanbul: Beyan Yayınları, 2017), 133.

98 Ebû Ubeyd, Kitâbü'l-emvâl, 675-677.

99 İbn Sa'd, Kitâbü't-tabakâti'l-kebîr, 5/332.

100 İbnü'l-Esîr, Üsdü'l-ğabe fi marifeti's-sahabe, 5/106; İbn Hacer, el-İsâbe fi temyizi's-sahabe, 6/28.

${ }^{101}$ Ebû Ubeyd, Kitâbü'l-emvâl, 503.

102 el-Belâzurî, Fütûhu'l-büldân, 104.

${ }^{103}$ Ebû Ubeyd, Kitâbü'l-emvâl, 708-709.
} 
verdiği gibi kendisine şekil vereceğini de eklemiştir. Hz. Ömer, Muhammed'in kendisine yönelik bu cesur duruşu karşısında Allah'a hamd etmiştir. ${ }^{104}$

\subsection{Hz. Osman}

Hz. Osman'ın halifeliğinin son yıllarında taşrada halkla valiler arasında bazı problemler ortaya çıtı. Bu olaylar zaman içerisinde büyüdü ve halifenin yönetimini tehdit etmeye başladı. Zira hemen hemen her gün başkent Medine'ye valilerini şikâyet etmek amaciyla heyetler gelmeye başladı. Bunun üzerine halife, Medine'nin ileri gelenleriyle konuyu istişare etmek istedi. Onlara: "Sizler benim yönetim işinde ortaklarımsınız ve müminlerin de şahitlerisiniz. Taşradan gelen haberlerin mahiyetini anlatın ve bu konuda bana destek olun." Onlar da "Diğer şehirlerde olup bitenleri öğrenmek amacıyla güvendiğin adamlarından bazlların görevlendirmeni tavsiye ederiz. Onlar sana taşrada nelerin yaşandı̆̆ını net bir dille anlatsınlar." dediler. ${ }^{105}$

Hz. Osman, onların bu görüşlerini isabetli buldu ve Basra'ya Usâme b. Zeyd'i, Fustat'a/Kahire Ammâr b. Yâsir'i, Şam'a Abdullah b. Ömer'i ve en sıkıntılı şehirlerden biri olan Kûfe'ye de Muhammed b. Mesleme'yi görevlendirdi. Muhammed, Kûfe'ye gittiğinde hem oranın ileri gelenleriyle hem de halkla görüştü. Ancak toplumu ifsat eden ciddi bir tehlikeyle karşılaşmadı. Bu durumu da Halife Osman'a haber verdi. ${ }^{106}$

Hz. Osman'ın Muhammed'i Kûfe gibi sıkıntılı bir yere müfettiş olarak görevlendirmesi, onun Hz. Peygamber'in güvenine mazhar olması, Hz. Ömer'in halifeliği dönemlerinde denetleme işi olduğunda akla gelen ilk kişi olması, daha önce Sa'd b. Ebî Vakkas'ı teftiş etmek amacıyla Kûfe'ye gitmesi ve bu konuda yeterli derecede tecrübe sahibi olmasından kaynaklanmış olmalıdır. ${ }^{107}$

\subsubsection{Hz. Osman'ın Muhasara Edilmesi ve Şehadeti}

Hz. Osman, bütün çabalarına rağmen taşrada meydana gelen olayların önüne geçemedi. Her gün artan şikâyetler yüzünden bazı grupları memnun edemedi. Nitekim idarecilerinden rahatsız olan Mısırlı bir grup, halifeyle görüşmek için $\mathrm{Zu}$ Huşub denen yere geldiler. Durumdan haberdar olan Hz. Osman, Muhammed b. Mesleme' yi ${ }^{108}$ onlarla görüşmek için göndererek geri dönmelerini, halifenin kendilerinden razı olduğunu, isteklerinin yerine geleceğini, hoşnut olmayıp tenkit ettikleri idarecilerini görevden alacağını ve onların yerine istedikleri idarecileri görevlendireceğini bildirmesini istedi. Muhammed, yanına elli süvari alarak Zu Huşub'a giderek Mısırlılara halifenin isteklerini bildirdi ve onları ikna etmeyi başard1. ${ }^{109}$

Mısır heyeti, Muhammed'in dediklerine uymuş ve dönmek için hazırlık yapmışlardı. Bu esnada grup başkanı İbn Udeys, Muhammed'e, "bize tavsiye edeceğin bir şey var mı?" diye sorduğunda Muhammed de ona şöyle karş1lık verdi: "Evet, Allah'tan korkmanı ve seninle buraya gelenleri alıp götürmeni ve onları halifemizden uzak tutmanı istiyorum. Çünkü o size yardımcı olacağına dair söz verdi." Daha sonra Mısır heyeti geri döndü. ${ }^{110}$

104 Alî b. Hüsâmiddîn b. Abdilmelik, Kenzü'l- 'ummâl fi's-süneni'l-akvâl ve'l-ef'âl (Beyrut: Müessesetu'r-Risâle, 1981), 12/563 (35764).

105 İbnü'l-Esîr, el-Kâmil fi't-târih, 2/526; Ahmed Cevdet Paşa, Kısas-ı Enbiya, 1/376.

106 İbnü'l-Esîr, el-Kâmil fi't-târih, 2/526-527; İbn Haldûn, Kitâbü'l- '̇̉ber, 2/587.

107 Yasin Kurnaz, Muhammed b. Mesleme Hayatı ve Şahsiyeti (Konya: Selçuk Üniversitesi, Yüksek Lisans Tezi, 2008$), 55$.

${ }^{108}$ Bazı kaynaklara göre Muhammed, Hz. Ali ile birlikte Mısır heyetiyle konuşmuşlar. İbnü'l-Esîr, el-Kâmil fi't-târih, 2/532.

109 İbn Sa'd, Kitâbü't-tabakâti'l-kebîr, 3/61; Zehebî, Târîhu'l-İslam, 3/122.

110 İbnü'l-Esîr, el-Kâmil fi't-târih, 2/532. 
Heyet Mısır'a doğru yola çıktı. Büveyb denen yere geldiklerinde zekât damgasıyla mühürlenen ${ }^{111}$ bir deveye denk geldiler. Deve sahibini sorguladıklarında Hz. Osman'ın kölesi olduğunu anladılar. Daha sonra eşyasını aradıklarında içerisinde Mısır valisi Abdullah b. Sa'd b. Ebı Serh'e hitaben yazılmış bir mektup buldular. Mektubun içeriğinde ise gelen heyetin cezalandırılması yazıyordu. Bu durumu gören heyet, Mısır'a gitmekten vazgeçip Medine'ye geri döndü. ${ }^{112}$

Muhammed b. Mesleme, Misır heyetinin geri geldiğinden haberdar olunca hemen onların yanına gitti ve neden geri döndüklerini sordu. Onlar da yolda yaşadıklarını anlatarak söz konusu mektubu gösterdiler. Bunun üzerine Muhammed, Hz. Ali'yi de yanına alarak Misır heyetiyle birlikte Hz. Osman'ın huzuruna çıktılar. Hz. Osman'ın yanına Mervan b. Hakem de gelmek istedi ancak Hz. Osman ona müsaade etmedi. Muhammed ve Hz. Ali, Misırlıların elindeki mektubu halifeye gösterdiler. Hz. Osman, mektubu gördüğünde "Allah'a yemin ederim ki bu mektubu ben yazmadım ve bundan kesinlikle haberdar değilim." dedi. Hz. Osman'ın yemini üzerine Muhammed b. Mesleme, "Halife doğru söylüyor. Bu Mervan'ın işidir." karşıllğıını verdi. Muhammed ve Hz. Ali'nin bütün çabalarına rağmen Mervan'ı gerektiği gibi sorgulamayan ve ona herhangi bir ceza vermeyen halife, yanında bulunanların desteğini de kaybederek yalnız kald1. ${ }^{113}$

Hz. Osman, çaresiz kaldığı bir anda tekrar Muhammed b. Mesleme'yi onları durdurmak ve sakinleştirmek için göndermek istese de Muhammed, bu defa kendisine verilen görevi kabul etmedi. Daha sonra Mısır'dan gelen heyet halifenin evini ablukaya aldıktan sonra onu şehit ettiler. ${ }^{114}$

\section{Sonuç}

Cesaret ve kahramanlığı ile bilinen Muhammed b. Mesleme, "Hz. Peygamber'in süvarisi" lakabına mazhar olmuştur. Askerî alanındaki kabiliyetinden dolayı Hz. Peygamber tarafından bazı seriyelerde komutanlık görevi verilmiştir. Aynı zamanda çalışkanlığı ve iş bitiriciliği sayesinde müteaddit defalar Müslümanları rahatlatıcı adımlar atmıştır.

Vefakârlığı ve sadakatiyle bilinen Muhammed b. Mesleme, birçok kişinin yalnız bıraktığ Hz. Peygamber'i en zor anlarında bile yanından ayrılmaması ve canı pahasına koruması, ona karşı olan bağlılığının bir göstergesidir.

Müslümanlara olan ahdini bozarak müşriklerle bir olup Hz. Peygamber'i hicveden Ka'b b. Malik, Müslümanların hukukunu hiçe sayarak çiğnemiştir. Dolayısıyla Hz. Peygamber tarafından katli helal kılınmıştır. Bu durumu öğrenen Muhammed b. Mesleme, hiç tereddüt etmeden ortaya atılmış ve onu öldürmüştür. Bu durum onun İslami hamiyetinin zirvede olduğunun bir kanıtıdır.

Liyakatli kişileri göreve getirmekle meşhur olan Hz. Ömer, görevlendirdiği memurlarını sürekli denetime tabi tutmuş ve bu iş için genellikle Muhammed b. Mesleme' ye görev vermiştir. Muhammed, Hz. Ömer'in halifeliği döneminde devletin genel müfettişi konumundaydı. Herhangi bir beldede halifenin memurları ile alakalı şikâyet söz konusu olduğunda Hz. Ömer, hiç düşünmeden onu göndermiştir. $\mathrm{O}$ da görevini yerine getirirken son derece titiz

111 İbn Sa'd, Kitâbü't-tabakâti'l-kebîr, 3/61; Hz. Peygamber'den itibaren zekâta taalluk eden hayvanlar damgalanırdı. Bk. Buhârî, Zekât, 69.

112 İbn Sa'd, Kitâbü't-tabakâti'l-kebîr, 3/48.

113 İbnü'l-Esîr, el-Kâmil fi't-târih, 2/537.

114 İbn Sa'd, Kitâbü't-tabakâti'l-kebîr, 3/48. 
davranmıştır. Denetlemek amacıyla gittiği yerlerde şikâyet ile ilgili konuyu etraflıca araştırmış ve bunun hakkında farklı kişilerin görüşlerine başvurarak olayların içyüzünü öğrenmeye çalışmıştır. Olay hakkında genel bir kanaate sahip olduktan sonra durumu Halife Ömer'e rapor etmiştir. Dolayısıyla Muhammed, Hz. Ömer'in halifeliği döneminde daha çok denetleme kimliğiyle ön plana çıkmış ve halifenin vazgeçemediği bir müfettişi olmuştur.

Muhammed b. Mesleme, Hz. Osman'ın halifeliğinin son dönemlerinde çıkan fitne olaylarını bertaraf etmede aktif rol oynamıştır. Daha önceki tecrübelerinden de faydalanan Hz. Osman, asileri durdurma görevini kendisine vermiştir.

Müslümanlar arasında farklı görüşler ortaya çıkıp tarafların birbirlerine kılıç çektikleri bir dönemde, Hz. Peygamber'in fitne ile ilgili hadisini öne sürerek olaylara müdahil olmamıştır. Bunun için Hz. Ali'ye biat etmediği gibi Müslümanlar arasında çıan savaşlara da iştirak etmemiş ve köşesine çekilerek Rebeze'de münzevi bir hayat yaşamıştır.

\section{Kaynakça}

Abdurrahman Re'fet el-Bâş̧a-Halid Muhammed Halid-Abdulaziz eş-Şennâvî. Sahabe Hayatından Tablolar. çev. Tâceddin Uzun. Konya: Kervan Yayınları, 2018.

Ahmed Cevdet Paşa. Kısas-ı Enbiya ve Tevârih-i Hulefâ. çev. Metin Muhsin Bozkurt. 2 Cilt. İstanbul: Çile Yayınları, ts.

Arslantaş, Nuh. Yahudilere Göre Hz. Muhammed ve İslâmiyet: İbranîce Tarih kitapları Açısından Bir İnceleme. İstanbul: İz Yayıncilık, 2011.

Ataullah Şahyar. "Muhammed b. Mesleme". Türkiye Diyanet Vakfi İslam Ansiklopedisi. 555556. Erişim 18 Ağustos 2020. https://islamansiklopedisi.org.tr/muhammed-b-mesleme

Avcı, Casim. "Kûfe". Türkiye Diyanet Vakfı İslam Ansiklopedisi. 339-342. Erişim 04 Ağustos 2020. https://islamansiklopedisi.org.tr/kufe

Belâzurî, Ahmed b. Yahya b. Câbir b. Davud el-. Ensâbu'l-eşrâf. 13 Cilt. Beyrut: Dâru'l-Fikr, 1996.

Belâzurî, Ahmed b. Yahya b. Câbir b. Davud el-. Fütûhu'l-büldân. Beyrut: Mektebetü'lMeârif, 1987.

Buhârî, Ebû Abdullah Muhammed b. İsmail. el-Câmi 'u's-sahîh. Beyrut: Dâru İbn Kesîr, 2003.

Câbirî, Muhammad Âbid el-. Arap ahlaki akli: Arap kültüründeki değer düzenlerine yönelik çözümleyici eleştirel bir araştırma. çev. Muhammed Çelik. İstanbul: Mana Yayınları, 1. baskı.

Diyârbekrî, Huseyn b. Muhammed b. Hasan. Târîhu'l-hamîs fi ahvâli'l-enfesi nefís. 2 Cilt. Beyrut: Daru Sadr, ts.

Ebû Dâvûd, Ebû Dâvûd Süleyman b. Eş'as es-Sicistâni el-Ezdî. Sünenu Eb̂̀ Dâvud. 2 Cilt. Beyrut: Dâru'r-Risâletu'l-Âlemiye, 2009.

Ebû Ubeyd, Ebû Ubeyd, Kasım b. Sellam. Kitâbü'l-emvâl. thk. Dr. Muhammed Ammare. Beyrut: Darü'ş-Şuruk, 1989.

Ebû Yusuf, Ebû Yusuf Ya'kub b. İbrahim. Kitabü'l-harâc. Beyrut: Darü'1 Ma'rife, 1979.

Fayda, Mustafa. Allah'ın Kılıcı Halid b. Velid. İstanbul: İFAV Yayınları, 6. Baskı., 2016.

Fayda, Mustafa. "Hz. Ömer Devri”. Doğuştan Günümüze Büyük İslam Tarihi. İstanbul: Çağ Yayınları, 1986.

Halîfe b. Hayyât, Ebû Amr Halîfe b. Hayyât b. Halîfe eş-Şeybânî el-Basrî. Tabakat. thk. Süheyl Zükkar. Beyrut: Daru'l-Fikr, 1993.

Halîfe b. Hayyât, Ebû Amr Halîfe b. Hayyât b. Halîfe eş-Şeybânî el-Basrî. Târîhu Halife $b$. Hayyât. Riyad: Dâru Tayyibe, 1985.

Hindî, Alî b. Hüsâmiddîn b. Abdilmelik b. Kadîhân el-Müttakī el-Hindî el-Müttakī el-. Kenzü'l- 'ummâl fi's-süneni'l-akvâl ve'l-ef'âl. Beyrut: Müessesetu'r-Risâle, 1981. 
İbn Abdilberr, Ebû Ömer Cemâlüddîn Yûsuf b. Abdillâh b. Muhammed b. Abdilberr enNemerî. el-İstî 'âb fì ma 'rifeti'l-ashâb. 4 Cilt. Beyrut: Daru'l-Cîl, 1992.

İbn Abdürabbih, Ebû Ömer Şihâbüddîn Ahmed b. Muhammed b. Abdirabbih b. Habîb elKurtubî el-Endelüsî. el-Ikdu'l-ferîd. Beyrut: Dâru'l-Kutubi'l-İlmiyye, 1983.

İbn Hacer, Ebu'l-Fadl Ahmed b. Ali b. Muhammed b. Ahmed b. Hacer el-Askalânî. el-İsâbe fi temyizi's-sahabe. thk. Adil Ahmed Abdulmevcûd-Ali Muhammed Muavviz. 8 Cilt. Beyrut: Daru'l-Kutubi'l-i̇lmiyye, 1415.

İbn Haldûn, Ebû Zeyd Abdurrahmân b. Muhammed. Kitâbü'l- '̇ber. thk. Halil Şehâde. Beyrut: Daru'l-Fikr, 1988.

İbn Haldûn, Ebû Zeyd Veliyyüddîn Abdurrahmân b. Muhammed. Mukaddime. çev. Halil Kendir. 2 Cilt. Ankara: İmaj Yayınevi, 2004.

İbn Hazm, Ebu Muhammed Ali b. Ahmed b. Sâid b. Hazm el-Endelüsî. Cevâmiu's-sîre. çev. M. Salih Arı. İstanbul: Çıra Yayınları, 2004.

İbn Hibbân, Ebû Hâtim Muhammed b. Hibbân b. Ahmed el-Büstî. es-Sîretü'n-nebeviyye ve ahbâru'l-hulefâ. ed. Mehmet Azimli. çev. Harun Bekiroğlu. 4 Cilt. Ankara: Ankara Okulu Yayınları, 2017.

İbn Hişam, Ebû Muhammed Cemâlüddîn Abdülmelik. es-Sîretu'n-nebeviyye. Beyrut: Dâru'lKitabu'l-Arabî, 1990.

İbn İshâk, Muhammed b. İshâk b. Yesâr. Sîretu İbn İshâk. thk. Muhammed Hamidullah. Konya: Hayra Hizmet Vakfı Neşriyat, 1981.

İbn Kayyim el-Cevziyye, Muhammed b. Ebi Bekir b. Eyyub b. Sa'd Şemsuddin b. Kayyim elCevziyye. Zâdu'l-meâd fi hedyi hayri'l-ibâd. 6 Cilt. Beyrut: Müessesetu'r- Risale, 1994.

İbn Kesîr, Ebu'l-Fida İsmail b. Ömer. el-Bidâye ve'n-nihâye. 15 Cilt. Beyrut: Mektebetu'lMaârif, 1990.

İbn Kuteybe, Ebû Muhammed Abdullah b. Müslim b. Kuteybe ed-Dîneverî. el-İmâme ve'ssiyâse. 6 Cilt. Beyrut: Daru'l-Adva, 1990.

İbn Sa'd, Muhammed b. Sa'd b. Menî ez-Zührî. et-Tabakâtü'l-kübra. thk. İhsan Abbas. 8 Cilt. Beyrut: Daru Sadr, 1968.

İbn Sa'd, Muhammed b. Sa'd b. Menî ez-Zührî. Kitâbü't-tabakâti'l-kebîr. 11 Cilt. Kahire: Mektebetü'l-Hâncî, 2001.

İbn Seyyidünnâs, Ebü'l-Feth Fethuddîn Muhammed b. Muhammed b. Muhammed elYa'merî. 'Uyûnü'l-esser fî fünûni'l-meġāzî̀ ve'ş-şemâ'il ve's-siyer. thk. İbrahim Muhammed Ramazan. 2 Cilt. Beyrut: Darü'l-Kalem, 1993.

İbn Şihâb ez-Zührî, Muhammed b. Müslim b. Ubeydullah İbn Şihâb ez-Zührî. el-Meğâzî. ed.

Mehmet Azimli. çev. Mehmet Nur Akdoğan. Ankara: Ankara Okulu Yayınları, 2016.

İbnü'l-Cevzî, Ebü'l-Ferec Cemâlüddîn Abdurrahmân b. Alî b. Muhammed el-Bağdâdî. elMuntazam fî târîhi'l-mülûk ve'l-ümem. 19 Cilt. Beyrut: Dâru'l-Kutubi'l-İlmiyye, 1992.

İbnü'l-Esîr, İzzuddin Ebü'l Hasan Ali b. Muhammed. el-Kâmil fi't-târih. thk. Ömer Abdusselam et-Tedmirî. 10 Cilt. Beyrut: Dârü’1 Kitâbi'l Arabiyye, 1997.

İbnü'l-Esîr, İzzuddin Ebü'l Hasan Ali b. Muhammed İbnü'l-Esîr. Üsdü'l-ğabe fi marifeti'ssahabe. 8 Cilt. Beyrut: Darü'1 Kütübi'1 İlmiyye, 1994.

Kallek, Cengiz. Asr-ı Saâdet'te Yönetim-Piyasa İlişkisi. İstanbul: İz Yayıncılık, 1997.

Kettânî, Muhammed Abdulhay. et-Teratibu'l-idâriyye. 2 Cilt. Beyrut: Darü'l-Erkam b. Ebi'lErkam, ts.

Kudâme b. Ca'fer, Ebü'l-Ferec Kudâme b. Ca'fer b. Kudâme b. Ziyâd el-Kâtib el-Bağdâdî. elHarâc ve sinâ'atu'l-kitâbe. thk. Muhammed Zeydî. Bağdat: Dâru'r-Raşîd, 1981.

Kurnaz, Yasin. Muhammed b. Mesleme Hayatı ve Şahsiyeti. Konya: Selçuk Üniversitesi, Yüksek Lisans Tezi, 2008. 
Mehmed Âşsk Hanefî. Târîh-i Mekke-i Mükerreme ma'al Medîne-i Münevvere. çev. Mehmet Karataş-Davut Adlığ-Abdullah Cengiz. Ankara: Gece Akademi, 2019.

Muhammad Hamidullah. Hz. Peygamber'in Savaşları. çev. Nazire Erinç Yurter. İstanbul: Beyan Yayınları, 2012.

Muhammed Hamidullah. Allah'ın Elçisi Hz. Muhammed. çev. Ülkü Zeynep Babacan. İstanbul: Beyan Yayınları, 2017.

Muslim, Ebu'l Huseyn el-Haccâc el-Kuşeyrî en-Nîsâbûrî. Sahîh'u-Muslim. Riyad: Dâr'uTaybe, 2006.

Ömerî, Abdulaziz b. İbrahim el-Ömerî. el-Vilayetu ala'l-buldan fi asri'l-hulafâi'r-raşidîn. Riyad: Dâru İşbiliyâ, 2001.

Taberî, Ebu Ca'fer Muhammed b. Cerîr. Târîhu'r-rusûl ve'l-mulûk. thk. Muhammed Ebû'lFadl İbrahim. 11 Cilt. Kahire: Dâru'l-Meârif, ts.

Vâkidî, Ebû Abdillâh Muhammed b. Ömer b. Vâkıd. Kitâbu'l-meğâzi. 3 Cilt. Beyrut: Dâru'lA'lemî, 1989.

Yakut, Ebu Abdullah b. Abdillah el-Hamevî. Mu'cemü'l-buldân. 5 Cilt. Beyrut: Dâru's-Sadr, 1977.

Yusuf el-Kardâvî. İslam Hukukunda Zekât. çev. İbrahim Sarmış. 2 Cilt. İstanbul: Kayıhan Yayınları, 1984.

Zehebî, Ebû Abdillâh Şemsüddîn Muhammed b. Ahmed b. Osmân ez-. Târîhu'l-İslam ve vefeyâtu'l-meşâhîr ve'l-a'lam. thk. Beşar Avvâd M'rûf. 15 Cilt. Beyrut: Dâru'l-Garbi'l-İslâmî, 2003. 